\title{
O DIREITO À IDENTIDADE E A ALTERAÇÃO DO NOME/SEXO REGISTRAL: A (DES)NECESSIDADE DE REALIZAÇÃO DE CIRURGIA DE REDESIGNAÇÃO SEXUAL
}

\author{
Eduardo Biacchi Gomes* \\ Ane Elise Brandalise Gonçalves**
}

SUMÁRIO: Introdução; 2 O Direito À Identidade, o Pedido de Alteração de Nome/ Sexo Registral e a ADIN 4275; 3 Argumentos Prós e Contras Acerca da Cirurgia de Redesignação Sexual; 4 Considerações Finais; Referências.

RESUMO: O presente artigo busca apresentar a atual discussão que gira em torno dos pedidos judiciais de retificação do nome civil, qual seja: a necessidade ou não da realização da cirurgia de redesignação sexual para obtenção da almejada alteração do registro civil. A questão ainda permanece sem resposta definida no Judiciário, ao que se aguarda a decisão do Supremo Tribunal Federal sobre o assunto (Ação Direta de Inconstitucionalidade $\mathrm{n}^{0} 4275$, em trâmite desde 2009). A hipótese deste trabalho centra-se no fato de que muitas pessoas ainda estão à mercê de um entendimento e de uma solução que leve em consideração valores como a dignidade da pessoa humana, de forma a preservar a sua identidade. Para tanto, o STF, quando no julgamento da $\mathrm{ADIN} 4275$, há de sopesar na balança os prós e contras de cada posicionamento acerca do tema. Por fim, quanto à metodologia, o artigo é teórico-dedutivo, com fundamentação alicerçada no tripé jurídico legislação, doutrina e jurisprudência (com destaque a esta última), bem como fez uso de outras fontes capazes de explicitar a questão em tela. A pesquisa tem caráter qualitativo e buscou desvendar as decisões emitidas pelo Judiciário através da análise de conteúdo do discurso judicial.

PALAVRAS-CHAVE: ADIN 4275; Alteração do Nome/Sexo Registral; Cirurgia de Redesignação Sexual; Direito à Identidade; Mudança de Sexo; Retificação.

\section{RIGHT TO IDENTITY AND CHANGES IN NAME/GENDER ON BIRTH REGISTER: THE NEED OR NOT OF SURGERY FOR SEXUAL REDESIGNATION}

ABSTRACT: Current essay discusses the judicial demands to rectify the civil name or the need of surgery for sexual re-designation to obtain the desired modification

\footnotetext{
Docente Permanente do Programa de Pós-Graduação Stricto sensu Mestrado do Centro Universitário UNIBRASIL uritiba (PR), Brasil; Docente dos Cursos de Graduação de Direito e Relações Internacionais da UNINTER; E-mail: ebgomes@icloud.com

** Mestranda no Programa de Pós-Graduação Stricto sensu em Direitos Fundamentais e Democracia do Centro Universitário UNIBRASIL, Curitiba (PR), Brasil
} 
in the birth certificate. The issue has not been answered by the Courts since the decision by the Brazilian Supreme Court is awaited on the subject (Direct Suit on Non-constitutionality 4275, running since 2009). The hypothesis is based on the fact that many people depend on an understanding and a solution that takes into account such values as human dignity so that identity is preserved. The Brazilian Supreme Court in its ruling on ADIN 4275 has to put in the balance favorable and contrary arguments with regard to the subject matter. The theoretical and deductive methodology is based on legislation, doctrine and jurisprudence (especially the last) and other sources which explicit the issue. Current qualitative research reveals decisions by the Courts by content analysis of the juridical discourse.

KEY WORDS: ADIN 4275; Alteration of Name/Gender in Birth Certificate; Sexual Redesignation Surgery; Right to Identity; Gender Change; Rectification.

\section{DERECHO A LA IDENTIDAD Y LA ALTERACIÓN DEL NOMBRE/ SEXO REGISTRAL: LA (IN) NECESIDAD DE LA REALIZACIÓN DE CIRUGÍA DE REDESIGNACIÓN SEXUAL}

RESUMEN: El presente artículo busca presentar la actual discusión en relación a los pedidos judiciales de rectificación del nombre civil dónde orbita la necesidad o no de la realización de la cirugía de re designación sexual para obtención de la alteración del registro civil. La cuestión todavía permanece sin respuesta definida en el Judiciario y aguarda la decisión del Supremo Tribunal Federal sobre el asunto (Acción Directa de Inconstitucionalidad no 4275 , en trámite desde 2009). La hipótesis de este trabajo se centra en el hecho de que muchas personas todavía están a espera de una solución que considere valores como la dignidad de la persona humana, de forma a preservar la identidad. Para tal, el STF, en el juzgamiento de la ADIN 4275, debe considerar los puntos positivos y negativos de cada posición en relación a ese tema. Por fin, en relación a la metodología, el artículo es teórico-deductivo, con fundamentación basada en el trípode jurídico legislación, doctrina y jurisprudencia (con destaque a esta última), bien como hace uso de otras fuentes para explicitar la cuestión en discusión. La investigación posee carácter cualitativo y buscó desvendar las decisiones emitidas por el judiciario por medio del análisis de contenido del discurso judiciario.

PALABRAS-CLAVE: ADIN 4275; Alteración del Nombre/Sexo Registral; Cirugía de re Designación Sexual; Derecho a la Identidad; El Cambio de Sexo; Rectificación. 


\section{INTRODUÇÃO}

O presente artigo visa analisar e apresentar a questão da (des)necessidade de submissão da cirurgia de redesignação sexual àquelas pessoas que necessitam aforar iniciais para alteração de nome/sexo constantes em Registro Civil a fim de ver suas identidades civis em consonância com as respectivas identidades psicológicas e sociais, submetendo ao Judiciário a função de resguardar uma gama de direitos inerentes à pessoa humana, como ser individual, e inerentes à toda sociedade.

Para tanto, é necessário demonstrar como funciona, normalmente, a tramitação dessas ações iniciais (requisitos necessários, documentação, fundamentos principais das decisões, etc), sem olvidar da menção à ADIN 4275, a qual ainda se encontra pendente de julgamento pelo Supremo Tribunal Federal, doravante denominado STF.

Do mesmo modo, insta verificar a atual jurisprudência, por meio de decisões de tribunais variados, incluindo decisões exaradas pelo Supremo Tribunal de Justiça, doravante chamado de STJ.

De qualquer forma, é preciso clarificar quais são os posicionamentos, da doutrina e jurisprudência, atinentes à (des)necessidade de realização da cirurgia de redesignação sexual (conhecida também como cirurgia de transgenitalização). No ponto, cumpre anotar que este artigo, como pesquisa imparcial, não faz menção direta a ações acerca de retificação de nome/sexo registral, eis que normalmente essas tramitam em segredo de Justiça.

Ainda assim, utilizou-se no artigo como fonte as principais decisões publicadas acerca do tema, bem como fez uso dos sítios eletrônicos do STF e STJ, que disponibilizam a análise do andamento processual e publicação das principais decisões dos processos aqui comentados.

Ora, como ainda não há uma resposta única ao tema, ao que se aguarda a decisão do STF na ADIN 4275, há de sopesar na balança os prós e contras dos variados posicionamentos contidos na doutrina e na jurisprudência (com destaque a decisões do STJ), o que far-se-á por meio da análise de conteúdo de decisões judiciais selecionadas. Frise-se que longe de adentrar na seara cultural ou psicológica do ser humano, o presente trabalho, como pesquisa imparcial que pretende ser, não tem como fito exarar qualquer opinião de caráter discriminatório, tendo como objetivo maior apresentar os variados posicionamentos sobre o caso em tela. 
Perpassada a análise de conteúdo de decisões judiciais de Tribunais de vários Estados sobre o assunto (respectivamente: Minas Gerais, Rio de Janeiro, Sergipe), com os pontos positivos e negativos colocados no papel, chega-se às considerações finais do artigo, avultando que o tema do pedido de readequação do registro civil ainda merece discussões e estudos aprofundados, sempre em prol do ser humano.

Por fim, quanto à metodologia, o artigo é teórico-dedutivo, com fundamentação alicerçada no tripé jurídico legislação, doutrina e jurisprudência, bem como fez uso de documentos outros capazes de explicitar a questão em tela. A pesquisa tem caráter qualitativo e buscou desvendar as questões emitidas pelo Judiciário quando na análise dos pedidos de retificação de nome e sexo constantes em registro civil.

\section{O DIREITO À IDENTIDADE E A ALTERAÇÃO DE NOME/SEXO REGISTRAL: ADIN 4275 DO STF}

Para entender toda tramitação das ações envolvendo alteração do nome/ sexo constantes em registro civil, primeiramente faz-se necessário explicitar, sob a ótica jurídica, o que seriam os definidores de identidade humana e quais seus reflexos jurídicos na atual questão.

$\mathrm{O}$ direito à identidade consiste em um direito que engloba variadas facetas, todas correlatas à dignidade da pessoa humana, garantida pela Constituição da República Federativa Brasileira (Art. $1^{\circ}$, inciso III), tanto assim que o expert Adriano de Cupis denomina o direito à identidade como "os direitos da personalidade"1.

Assim, pois, o direito à identidade abarca outros tantos diversos direitos como os ligados à noção de identidade (verbi gratia o direito ao nome, ao reconhecimento genético, etc). No mais, é de se ver, sob certo viés, que o direito à identidade constitui-se direito humano universal, eis que todos os indivíduos são possuidores do direito à identidade da personalidade.

Acerca do nome, vale menção da distinção entre nome social e o nome civil: enquanto este (nome civil) é aquele registrado na certidão de nascimento, o nome social designa a forma pela qual a pessoa é identificada e reconhecida na sociedade.

O nome é uma das facetas da identidade humana, a qual, ao seu turno, pode

$\overline{1}$ DE CUPIS, Adriano. O Direito à Identidade Pessoal. In: Os Direitos da Personalidade. Trad. de Antonio Celso Furtado Rezende. Campinas: Romana, 2004. 
ser definida "no distinguir-se das outras pessoas nas relações sociais"2. Ressalte-se, nesta perspectiva, que o conceito de identidade pessoal não se confunde com o direito ao nome, em que pese este ser parte integrante daquele.

Indo mais além, outra faceta da identidade que merece menção, para muito além da esfera individual de cada um, mas envolvente de toda sociedade, ainda estritamente ligada às facetas do nome e do sexo, é a vertente cultural. Nessa toada, sabiamente explicita o antropólogo Roberto DaMatta acerca da identidade cultural ${ }^{3}$ :

[...] quando falamos da "casa", não estamos nos referindo simplesmente a um local onde dormimos, comemos ou que usamos para estar abrigados do vento, do frio ou da chuva. Mas - isto sim - estamos nos referindo a um espaço profundamente totalizado numa forte moral. Uma dimensão da vida social permeada de valores e de realidades múltiplas. Coisas que vêm do passado e objetos que estão no presente, pessoas que estão saindo deste mundo e pessoas que a ele estão chegando, gente que está relacionada ao lar desde muito tempo e gente que se conhece de agora. Não se trata de um lugar físico, mas de um lugar moral: esfera onde nos realizamos basicamente como seres humanos que têm um corpo físico, e também uma dimensão moral e social. Assim, na casa, somos únicos e insubstituíveis. Temos um lugar singular numa teia de relações marcadas por muitas dimensões sociais importantes, como a divisão de sexo e de idade. Mas se em casa somos classificados pela idade e pelo sexo como, respectivamente, mais velhos ou mais moços e como homens e mulheres - e aqui temos dimensões sociais que são provavelmente as primeiras que aprendemos na sociedade brasileira -, nela somos também determinados por tudo o que a "honra", a "vergonha" e o "respeito", esses valores grupais, acabam determinando.

$[\ldots]$

A conjunção de tudo isso faz com que nós, brasileiros, tenhamos uma percepção de nossas moradas como lugares singulares, espaços exclusivos. Pois cada casa, embora tenha os mesmos espaços e basicamente os mesmos objetos de todas as outras, é diferente delas. Todas são únicas, se não como espaço físico de morada, pelo menos como domínio onde se realiza uma convivialidade social profunda. Daí a possibilidade de diferenciar profundamente a casa ou a morada - o prédio - do lar. Mesmo quando são residências baratas ou casas de vila, construídas de modo idêntico, algo marca e revela sua identidade e, com isso, a identidade do grupo que a ocupa: um pedaço de azulejo estrategicamente colocado próximo de uma janela; um nome singelo na parte de cima da soleira da porta; flores e jardins; a cor de suas janelas e portas.

2 Ibidem, p. 179-180.

3 DA MATTA, Roberto. O que faz o brasil, Brasil? Rio de Janeiro, Rocco, 1986, p. 16-17. 
Retomando a esfera individual, para além do nome, outro integrante da identidade que possui especial relevância seria a identificação física da pessoa, a qual possui sua relevância e discussão para uma gama de assuntos e é, muitas vezes, a faceta definidora do lugar pertencente a cada um na sociedade, conforme explicitado por Roberto DaMatta.

Sobre esta faceta, é imperioso destacar que no momento do nascimento, o sexo biológico confunde-se com o sexo civil/jurídico, de forma que posterior alteração do registro civil depende de comprovação de nova identidade sexual do indivíduo. Hodiernamente, segundo o secretário de Estado da Educação de São Paulo, Herman Voorwald ${ }^{4}$ :

A identidade de gênero se refere à experiência íntima, individual e intransferível de cada ser humano consigo mesmo e que define, de forma profunda e abrangente, o gênero com que cada pessoa se identifica, se percebe. Esta identidade pode ou não corresponder ao sexo atribuído no nascimento. A identidade de gênero inclui o senso pessoal do corpo que eventualmente envolve, por livre escolha, modificação da aparência ou função corporal por meio de intervenções médicas, cirúrgicas ou outras.

Outras expressões de gênero, inclusive vestimenta, modo de falar e maneirismos também são eventualmente adotadas, sempre por livre escolha. Transexuais e travestis possuem identidade de gênero distinta de seu sexo biológico.

A orientação sexual e a identidade de gênero são essenciais para a dignidade e humanidade de cada pessoa e não devem ser motivo de discriminação ou abuso.

Assim sendo, quando determinado indivíduo se sente pertencente ao sexo oposto àquele declarado em sua certidão de nascimento, sendo, inclusive, socialmente considerado como pessoa diversa daquela constante em seu registro civil (em razão de vestimentas ou/e e/ou em razão dos seus atos no cotidiano), tem-se a possibilidade de aforar ação de alteração de nome/sexo registral, para fins de adequação do nome social com o nome civil e para evitar constrangimentos ocorridos em razão da dissonância de nomes 5 .

BRASIL, Estado de São Paulo. Indicação CEE no 126/2014 CP, aprovado em 30/4/2014. Disponível em: <www. centropaulasouza.sp.gov.br/cetec/geral/.../cee/125_2014.docx >. Acesso em: 16 fev. 2015.

5 Ainda que não seja a principal controvérsia que estuda o presente artigo, vale notar que há de se constatar a competência para o julgamento da demanda, ou seja, há de se verificar a priori o foro responsável para julgar as ações envolvendo retificação do Registro Civil, a qual pode se dar nas Varas de Registros Públicos ou, ao revés, nas Varas de Família, a depender das normas de cada Estado membro. O presente artigo perfilha-se ao entendimento de que as ações de readequação de nome/sexo constantes em registro civil devem tramitar nas Varas de Família, eis que se trata de ação de estado de pessoa, em processo que impende ampla cognição. 
No caso em estudo, "o transexual exige, além da mudança na aparência física, um reconhecimento de seu novo sexo que não passa apenas por sua aceitação social, mas pelo documento legal que vem atestá-lo"6.

O pedido, por si só, não é sinônimo de "procedência da ação", havendo de se comprovar que a identificação civil realmente não reflete sua personalidade individual da pessoa. Além disso, com o fito de se evitar eventual prejuízo a terceiros, é necessária a apresentação de certidões negativas (especialmente dos Serviços de Proteção ao Crédito SPC e SERASA e dos Cartórios Distribuidor - Cível e Criminal).

Há também, via de regra, a apresentação de documentos médicos para demonstrar a realização de tratamentos médicos e psicológicos para adequação da real identidade de gênero. Nessa documentação, é possível aferir que a pessoa tem a identidade trans, classificada como um "transtorno de identidade sexual", assim definido por meio da Classificação Internacional de Doenças F - 64.0 e conceituada pelo viés da Medicina como:

[...] um desejo de viver e ser aceito enquanto pessoa do sexo oposto. Este desejo se acompanha em geral de um sentimento de mal-estar ou de inadaptação por referência a seu próprio sexo anatômico e do desejo de submeter-se a uma intervenção cirúrgica ou a um tratamento hormonal a fim de tornar seu corpo tão conforme quanto possível ao sexo desejado.

É justamente em torno da definição médica, decorrente uso no discurso do Direito, que surge o seguinte questionamento: há a necessidade ou não do indivíduo passar pela cirurgia de redesignação sexual, denominada também de "cirurgia de transgenitalização"? Vale dizer: o pedido só pode ser deferido após a realização e comprovação da aludida cirurgia?

No ponto, explica Jussara Maria Leal de Meirelles que tais discussões são atinentes a um novo ramo do saber jurídico, o Biodireito, o qual deve levar em consideração em primeiro plano a vida humana e não pode ficar longe do saber jurídico. Em suas palavras, assim ensina sabiamente sobre o assunto a professora ${ }^{8}$ :

$[\ldots]$

Quando se faz menção a: reprodução artificial, manipulação de genes, transplante de órgãos, clonagem, aborto, eutanásia, esteri-

\footnotetext{
6 FRIGNET, Henry. O transexualismo. Trad. Procópio Abreu. Rio de Janeiro: Companhia de Freud, 2002, p. 93.

7 ORGANIZAÇÃO MUNDIAL DA SAÚDE. CID-10 Classificação Estatística Internacional de Doenças e Problemas Relacionados à Saúde. São Paulo: Universidade de São Paulo, 2013.

8 MEIRELLES, Jussara. A questão do Biodireito sob a ótica da construção dos novos direitos no Brasil. In: MATOS, Ana Carla Harmatiuk. (Org.). A construção dos novos direitos. Porto Alegre: Núria Fabris, 2008, v. 1, p. 216.
} 
lização, experimentação em seres humanos, psicocirurgia, órgãos artificiais, pré-seleção e troca de sexo, e tantas outras novidades biotecnológicas, logo vêm à lembrança o valor do ser humano e o respeito que lhe é devido.

Essa reflexão de consciência, que delineia limites morais às investigações e práticas biocentíficas, sem dúvida é influente na informação e formação do Direito. Existem, no entanto, questões essencialmente jurídicas, cuja solução não é possível limitar ao âmbito da consciência moral de cada um.

[...]

De igual forma, a tipificação do aborto, a eutanásia, o problema da identidade pessoal na troca de sexo; a responsabilidade civil, penal e administrativa concernente às empresas de engenharia genética; $\mathrm{e}$ tantos outros assuntos conexos.

Dentro do âmbito jurídico a questão da cirurgia de redesignação sexual é polêmica, sendo que ora há julgadores que compartilham do entendimento de que é preciso realizar a cirurgia, ora há aqueles que entendam que não se faz imprescindível a cirurgia de redesignação sexual para ser deferido o pedido.

Nesse sentido, verifica-se que a questão ganhou discussão no STF por meio da ADI $n^{0}$ 4275, intentada pela Procuradoria-Geral da República em 21/07/20099, visando conferir uma interpretação conforme a Constituição da República Federativa do Brasil sobre o artigo 58 da Lei $n^{\circ}$ 6.015/1973, segundo o qual "o prenome será definitivo, admitindo-se, todavia, a sua substituição por apelidos públicos notórios"10.

Com efeito, a interpretação conforme a Constituição é um método de interpretação que recai sobre uma lei, havendo como parâmetro a Constituição ${ }^{11}$. No caso em tela, como visto, tem-se como principais dispositivos guiadores o da dignidade da pessoa humana, fundamento da República Federativa do Brasil (art. 10 $^{\circ}$, inciso III), o direito à inviolabilidade da intimidade, da vida privada, da honra e da imagem das pessoas (art. $5^{\circ}$, inciso $\mathrm{X}$ ).

A ADI ainda não foi julgada pelo STF e atualmente está em fase de oitiva dos

9 BRASIL. Supremo Tribunal Federal. ADI $\mathrm{n}^{\mathrm{o}}$ 4275. Disponível em: < http://www.stf.jus.br/portal/processo/ verProcessoAndamento.asp?incidente $=2691371>$. Acesso em: 06 fev. 2015.

10 BRASIL. Lei $\mathrm{n}^{\mathrm{0}}$ 6.015, de 31 de dezembro de 1973. Disponível em: < http://www.planalto.gov.br/ccivil_03/ leis/16015compilada.htm > . Acesso em: 06 fev. 2015.

${ }^{11}$ Para saber mais sobre o que consiste a chamada interpretação conforme a Constituição e seus variados debates, vide: SILVA, Virgílio Afonso da. Interpretação conforme a constituição: entre a trivialidade e a centralização judicial. Revista Direito FGV, v. 3, p. 191-210, 2006. Disponível em: < http://bibliotecadigital.fgv.br/ojs/index. php/revdireitogv/article/viewFile/35221/34021>. Acesso em: 05 fev. 2015. 
amici curia ${ }^{12}$, de modo que a pessoa que chega com a intenção de alterar seu registro civil em prol de sua identidade pessoal fica à mercê dos variados entendimentos dos julgadores.

Além da $\mathrm{ADI} 4275$, é importante constatar que afora as ações de controle de constitucionalidade concentrado há também aquelas ações cujo controle de constitucionalidade se dá de modo difuso ${ }^{13}$, a exemplo mais recente do Recurso Extraordinário $n^{0} 670422$, em que a parte recorrente propugna violação às normas constitucionais e ao direito de identidade quando em decisão proferida que se fundamentou na necessidade de realização de cirurgia de modificação do fenótipo feminino para o masculino como condição para alteração do assentamento do sexo no registro civil $^{14}$.

Enquanto isso as decisões judiciais acerca do tema ora entendem que a pessoa deve se submeter à cirurgia de redesignação sexual, ora propugnam pela desnecessidade da cirurgia. Nos casos de pessoas já submetidas à aludida cirurgia certamente a questão é mais simples, havendo maiores chances de obtenção de êxito na demanda. Nesse sentido, inclusive, cite-se decisão do Tribunal de Justiça de Minas Gerais ${ }^{15}$ :

Retificação de registro de nascimento - transexual - cirurgia de transgenitalização já realizada - princípio da dignidade da pessoa humana - mudança de nome - necessidade para evitar situações vexatórias inexistência de interesse genérico de uma sociedade democrática à integração do transexual.

- A força normativa da constituição deve ser vista como veículo para

\footnotetext{
12 Termo em latim que significa "amigos da corte" (no singular: amicus curiae) e designa a intervenção assistencial em processos, sobre questão de direito pertinente à controvérsia. Não são partes dos processos, atuam apenas como interessados na causa. In: BRASIL, Supremo Tribunal Federal, Glossário Jurídico. Disponível em: $<$ http://www.stf.jus.br/portal/glossario/> . Acesso em: 20 jul. 2014.

13 Grosso modo, o controle de constitucionalidade significa a Constituição como norma de validade para os demais atos normativos do sistema jurídico. A Constituição é, pois, o parâmetro, a base, o modelo a ser seguido pelas demais normas de todo um sistema jurídico próprio. Tal controle pode ser realizado em determinado caso concreto, quando então passa a ser chamado de controle de constitucionalidade difuso, controle pela via de exceção ou defesa ou, ainda, controle aberto ou pode ser realizado por uma única via, um único Tribunal responsável pela verificação da (in)constitucionalidade da lei ou ato normativo questionada, quando então o controle passa a ser denominado de controle concentrado. Nesse último caso, cinco casos adequam-se ao controle concentrado: (1) ADI - ação direta de inconstitucionalidade; (2) ADPF - arguição de descumprimento de preceito fundamental; (3) ADO - ação direta de inconstitucionalidade por omissão; (4) IF - intervenção federal; (5) ADC - ação declaratória de constitucionalidade. In: BARROSO, Luís Roberto. O controle de constitucionalidade no direito brasileiro: exposição sistemática da doutrina e análise crítica da jurisprudência. $6^{\mathrm{a}}$ ed., rev., atual., São Paulo: Saraiva, 2012.

${ }^{14}$ Acerca deste aludido e relevante recurso, vide: BRASIL, Supremo Tribunal Federal. Alteração do registro civil sem mudança de sexo será analisada pelo STF. Notícias do STF. Disponível em: < http://www.stf.jus.br/portal/ $\mathrm{cms} /$ verNoticiaDetalhe.asp?idConteudo $=275563>$. Acesso em: 06 fev. 2015.

15 BRASIL, Tribunal de Justiça do Estado de Minas Gerais. Apelação Cível 1.0024.05.778220-3/001, Rel. Des.(a) Edivaldo George dos Santos, $7^{\text {a }}$ CÂMARA CÍvEL, julgamento em 06/03/2009.
} 
a concretização do princípio da dignidade da pessoa humana, que inclui o direito à mínima interferência estatal nas questóes íntimas e que estão estritamente vinculadas e conectadas aos direitos da personalidade.

- Na presente ação de retificação não se pode desprezar o fato de que o autor, transexual, já realizou cirurgia de transgenitalização para mudança de sexo e que a retificação de seu nome evitar-lhe-á constrangimentos e situações vexatórias.

- Não se deve negar ao portador de disforia do gênero, em evidente afronta ao texto da lei fundamental, o seu direito à adequação do sexo morfológico e psicológico e a consequente redesignação do estado sexual e do prenome no assento de seu nascimento.

Veja-se, porém, que não há de se olvidar de eventuais direitos de terceiros. Ou seja: deve constar no livro de registros (e apenas neste documento) a averbação da alteração. Confira-se atual entendimento do STJ acerca do assunto ${ }^{16}$ :

Tal providência decorre da necessidade de salvaguardar os atos jurídicos já praticados, objetiva manter a segurança das relações jurídicas e, por fim, visa solucionar eventuais questões que sobrevierem no âmbito do direito de família (casamento), no direito previdenciário e até mesmo no âmbito esportivo.

Conforme ver-se-á mais adiante tal fator vem sopesando a decisão de realização ou não da cirurgia de redesignação sexual. Ainda assim, àqueles que ainda não se submeteram ao procedimento cirúrgico (seja qual razão for) é preciso verificar, ao menos por ora, os prós e contras de cada posicionamento, como passa-se a analisar.

\section{ARGUMENTOS PRÓS E CONTRAS ACERCA DA CIRURGIA DE REDESIGNA- ÇÃO SEXUAL}

Há variados entendimentos quanto à necessidade ou não da intervenção cirúrgica e sua comprovação nos processos judiciais ora em questão. Explica-se.

$\mathrm{O}$ entendimento pela necessidade de submissão cirúrgica baseia-se nos mais variados argumentos, todos concluindo que a não comprovação da realização da cirurgia ou mesmo o desinteresse pela realização da cirurgia implicariam em ausência de interesse processual ou em improcedência ou procedência parcial do

\footnotetext{
${ }^{16}$ BRASIL, Superior Tribunal de Justiça. REsp 737993/MG. Rel. Min. João Otávio de Noronha, 4a Turma. DJ: 10/11/2009. Disponível em: <https://ww2.sti.jus.br/processo/revista/documento/mediado/?componente =ATC\&sequencial $=6511771 \&$ num_registro $=200500486064 \&$ data $=20091218 \&$ tipo $=91 \&$ formato $=P D F>$. Acesso em: 02 fev. 2015.
} 
pedido inicial.

Tal cirurgia seria, a priori, uma necessidade psicológica da pessoa, a qual não teria felicidade em sua vida sem a realização do procedimento cirúrgico. Ora, hodiernamente é assente no ordenamento jurídico brasileiro que se vive em uma sociedade eudemonista, ou seja, que procura satisfazer a felicidade, consectário da dignidade da pessoa humana ${ }^{17}$.

O posicionamento é reforçado pela Medicina e Psicologia (ao menos em grande parte dessas matérias), estampado especialmente por meio da mais recente Resolução $n^{0}$ 1955/10 do Conselho Regional de Medicina ${ }^{18}$. Explica sobre a aludida cirurgia a psicóloga Desiree Monteiro Cordeiro ${ }^{19}$ :

Especificamente no Brasil, a resolução do CFM de 2010 autoriza a realização de cirurgia de redesignação sexual do tipo neocolpovulvoplastia e/ou procedimentos complementares sobre gônadas e caracteres sexuais secundários como tratamento dos casos de transexualismo masculino e também as cirurgias de redesignação sexual do tipo mastectomia e/ou procedimentos complementares sobre gônadas e caracteres sexuais secundários como tratamento dos casos de transexualismo feminino, mas também a neofaloplastia como experimental. Além disso, assume que a definição de transexualismo obedecerá, no mínimo, os seguintes caracteres:

1. desconforto com o sexo anatômico natural;

2. desejo expresso de eliminar os genitais, perder as características primárias e secundárias do próprio sexo e ganhar as do sexo oposto; 3. permanência desse distúrbio de forma contínua e consistente por pelo menos dois anos;

4. ausência de outros transtornos mentais.

A seleção dos pacientes para cirurgia de transgenitalismo obedecerá à avaliação de equipe multidisciplinar constituída por médico psiquiatra, cirurgião, psicólogo e assistente social, segundo os critérios definidos, após dois anos de acompanhamento conjunto:

- diagnóstico médico de transexualismo;

- maior de 21 anos;

- ausência de características inapropriadas para cirurgia;

\footnotetext{
${ }^{17}$ BRASIL, Supremo Tribunal Federal. Informativo STF. STA 223-AgR, Rel. p/ o C. Min. Celso de Mello, julgamento em 14-4-08, Plenário, Informativo $\mathrm{n}^{0}$ 502. Disponível em: < http://www.stf.jus.br/arquivo/informativo/ documento/informativo502.htm > . Acesso em: 10 fev. 2015.

${ }^{18}$ CONSELHO FEDERAL DE MEDICINA. RESOLUÇÃO CFM n ${ }^{\circ} 1.955$ de 12 de agosto de 2010. Dispõe sobre a cirurgia de transgenitalismo e revoga a Resolução CFM n ${ }^{0}$ 1.652/02. Disponível em: <http://www.portalmedico. org.br/resolucoes/CFM/2010/1955_2010.htm > . Acesso em: 10 fev. 2015. É de se constatar que o transexualismo é tema circunscrito em três Resoluções médicas, quais sejam: CFM n ${ }^{0}$. 1.482/1997; CFM n ${ }^{0}$. 1.652/2002; e a mais recente, $C F M n^{\circ}$. 1.955/2010.

${ }^{19}$ CORDEIRO, Desiree Monteiro. Transtorno de Identidade de Gênero e mudança de prenome: laudo psicológico e justiça. Dissertação (Mestrado em Psiquiatria) - Universidade de São Paulo, p. 51-52. Disponível em: $<$ http://www.teses.usp.br/teses/disponiveis/5/5142/tde-07122012-143732/pt-br.php>. Acesso em: 16 fev. 2015.
} 
- consentimento livre e esclarecido, de acordo com a Resolução CNS n ${ }^{\circ}$ 196/1996;

- as cirurgias para adequação do fenótipo feminino para o masculino poderão ser praticadas em hospitais, públicos ou privados, com exceção da neofaloplastia, que permanece restrita aos hospitais universitários ou hospitais públicos adequados à pesquisa;

- as cirurgias para adequação do fenótipo masculino para o feminino poderão ser praticadas em hospitais, públicos ou privados, independentemente da atividade de pesquisa.

Observe-se que neste ponto a transexualidade é vislumbrada como uma doença, fazendo parte, inclusive, do rol de doenças elencadas pela Classificação Internacional de Doenças sob o $\mathrm{n}^{\circ}$ CID10 F-64.0, cujo sentido já foi vislumbrado.

Contudo, não é só do discurso médico que se valem os defensores da necessidade da realização da cirurgia de redesignação sexual. Nessa perspectiva, um dos argumentos jurídicos a justificar a necessidade da aludida cirurgia, para além da questão da felicidade e da dignidade da pessoa humana, estar-se-ia centrado no princípio da veracidade dos documentos públicos. Assim, inclusive é a definição de certidões, segundo o clássico Hely Lopes Meirelles ${ }^{20}$ :

Certidões são cópias ou fotocópias fiéis e autenticadas de atos ou fatos constantes de processo, livro ou documento que se encontre nas repartições públicas. Podem ser de inteiro teor ou resumidos, desde que expressem fielmente o que se contém no original de onde foram extraídas. Em tais atos o Poder Público não manifesta sua vontade, limitando-se a transladar para o documento a ser fornecido ao interessado o que consta de seus arquivos. As certidões administrativas, desde que autenticadas, têm o mesmo valor probante do original, como documento público que são.

Nesse sentido é o seguinte julgado do Tribunal de Justiça do Rio de Janei$\mathrm{ro}^{21}$ :

RETIFICAÇÃO DE REGISTRO CIVIL. TRANSEXUALISMO. EXCLUSÃO DO TERMO. IMPOSSIBILIDADE. PRINCÍPIO DA VERACIDADE DO REGISTRO PÚBLICO Apelação Cível. Ação de retificação de registro. Transexual. Pretensão de exclusão de tal termo do assentamento. Procedência parcial do pedido, com a alteração das expressões "filho" e "nascido" por "filha" e "nascida". Fatos e atos jurídicos levados a registro junto aos cartórios de registros públicos. Sujeição ao

${ }^{20}$ MEIRELLES, Hely Lopes, Direito Administrativo Brasileiro, São Paulo, Malheiros, 2000, p. 182.

${ }^{21}$ BRASIL, Tribunal de Justiça do Estado do Rio de Janeiro. Apelação no 2007.001.14071. Des. Gilberto Dutra Moreira, $10^{\mathrm{a}}$ CÂMARA CÍVEL. DJ: 05/09/2007. 
princípio da veracidade, o que obriga a reflexão da verdade real das informações a que dão publicidade, sob pena de nulidade. Gênero sexual que é definido sob o aspecto biológico cuja prova é feita por laudo de análise citogenética, que pode determinar precisamente o cromossomo sexual presente no DNA do indivíduo. Operação de mudança de sexo não tem o condão de alterar a formação genética do indivíduo, mas apenas adequar o seu sexo biológico-visual ao psicológico. Pretensão incongruente de modificar a verdade de tal fato, fazendo inserir o nascimento de um indivíduo de sexo masculino como se feminino fosse. Impossibilidade. Inexistência de critérios objetivos que permitam delimitar o sexo sob o ponto de vista psicológico, o que poderia levar a várias distorções. Potencial risco a direitos de terceiros quanto ao desconhecimento acerca da realidade fática que envolve o transexual. Direito à intimidade e à honra invocados pela autora-apelante, que não são suficientes para afastar o princípio da veracidade do registro público e preservar a intimidade e a honra de terceiros que com ela travem relações. Parecer do Ministério Público, em ambos os graus, nesse sentido. Desprovimento do recurso.

Em outras palavras: todo aquele que não se submete à cirurgia não pode ser conferida a alteração de gênero postulada porquanto estar-se-ia inserindo uma informação falsa em documento dotado de fé pública e de presunção de veracidade, fato tal que poderia ensejar complicações de caráter civil, administrativo e também penal. No mais, ainda que psicologicamente a pessoa sinta-se pertencente a sexo diverso, a certidão de nascimento atestaria o sexo do indivíduo no momento do nascimento, a partir de informações constatáveis por meio de exames citogenéticos.

Por outro lado, há os defensores da ideia de que a retificação do sexo constantes em registro civil independe da cirurgia de redesignação sexual. Os argumentos também são variados e também fazem o uso da Medicina e Psicologia.

Para estes, o procedimento cirúrgico é por demasiado arriscado, não se podendo exigir do indivíduo que se submeta a uma cirurgia apenas para ver seu pedido de retificação de registro civil realizado. Com efeito, em cirurgias como estas há o alerta médico de que o procedimento pode acarretar variadas complicações, como "cicatrizes e inchaços, despigmentação cutânea, perda de sensibilidade e vitalidade biológica na região operada, dores pós-operatórias, [...]”22.

Quanto à vertente constitucional da dignidade da pessoa humana, diz-se ser incabível manter em assento de nascimento do indivíduo a anotação de sexo dife-

${ }^{22}$ BERTOLI, Clínica. Consentimento Informado Mastoplastia. Disponível em: < http://www.clinicabertoli.com. br/download/Consentimentos_Mastoplastia.pdf > . Acesso em: 10 fev. 2015. 
rente da sua realidade psíquica, a qual, a seu turno, também admite variadas nuances $^{23}$. Agir do contrário significaria, pois, acarretar o sofrimento humano e, portanto, violar a dignidade da pessoa humana.

Ademais, há de se levar em conta todo preconceito e julgamentos que o transexual sofre no cotidiano, de forma que o pedido de retificação de registro civil nada mais seria que um direito básico humano.

Acerca do tema, destaca-se o seguinte julgado do Tribunal de Justiça de Sergipe $^{24}$ :

Retificação de assento de nascimento. alteração do constitucional e civil. retificação de registro civil. transexual não submetido a cirurgia de alteração de sexo. modificação do prenome. possibilidade. alteração do gênero biológico constante em seu registro de masculino para transexual sem ablação de genitália. inovação recursal. recurso não conhecido nesse ponto. I - Cabe, pois, ao ordenamento jurídico, o papel de garantir ao indivíduo transexual a sua plena inserção na sociedade em que vive por meio do respeito à sua identidade sexual, como um dos aspectos do direito à saúde, mediante autorização judicial para o procedimento cirúrgico de transgenitalização e a retificação do registro civil com mudança do prenome ao sexo desejado, independentemente da realização da cirurgia; II - A ausência de dispositivos legais que regulamentam a alteração do assento de nascimento em casos de transexualidade, não deve ser um óbice para concretização dos direitos e garantias fundamentais previstos pela ordem constitucional; III - Inquestionável o constrangimento ao qual é submetido todas as vezes em que, apesar de possuir aparência feminina, tem que fazer uso de um nome masculino. De fato, não ter reconhecida a identidade sexual a qual entende inequivocamente pertencer acaba lhe acarretando um sofrimento imensurável, além de lhe impedir de usufruir de todos os atributos de sua personalidade, bem como de ter reconhecido o direito de viver dignamente; IV - Aliás, fechar os olhos para a situação vexatória que vem sendo submetido a parte demandante, a qual, destaque-se, é reconhecida pela própria medicina, implicaria numa ofensa sem medida ao princípio da dignidade da pessoa humana, previsto no art. $1^{\circ}$, III da CF como fundamento da República Federativa do Brasil. Diante de tais considerações, entendo que deve ser procedida a alteração do prenome do autor em seu Registro Civil de Nascimento, como requerido na inicial. [...] VI - Recurso da parte autora conhecido em parte, e na parte conhecida provida. Recurso do Ministério Público não conhecido. Decisão

23 Apenas para dar um exemplo dessas variadas nuances, tem-se que há variados exemplos na história de transexuais que se arrependeram de ter realizado a cirurgia de redesignação. Mais recentemente, vide: <http:// www.dailymail.co.uk/news/article-2776090/Transsexual-10-000-surgery-NHS-wants-man-again.html> . Acesso em: 10 fev. 2015.

24 BRASIL, Tribunal de Justiça do Estado de Sergipe, Apelação Cível n ${ }^{0}$ 4148/2012, $1^{\text {a }}$ Vara Cível de Estância, Juíza Convocada, Julgado em 04/12/2012. 
unânime.

Há o entendimento que propugna que o uso de variada documentação médica e necessidade de cirurgia de redesignação por parte do Judiciário significa um apoderamento, ou seja, uma posse, do discurso da Medicina ao discurso jurídico, o qual apenas acaba por exarar a opinião de uma maioria que visa dominar outros grupos $^{25}$, especialmente ao classificar a transexualidade como uma patologia e não levar em consideração que a transexualidade pode adquirir uma série de nuances nem sempre interligadas à vontade de trocar de sexo.

Assim, por exemplo, cite-se o posicionamento da socióloga Berenice Ben$\mathrm{to}^{26}$ :

[...] O corpo-sexuado (o corpo-homem e o corpo-mulher) que dá inteligibilidade aos gêneros encontra na experiência transexual seus próprios limites discursivos, uma vez que aqui o gênero significará o corpo, revertendo um dos pilares de sustentação das normas de gênero. Ao realizar tal inversão, deparamo-nos com uma outra 'revelação': a de que o corpo tem sido desde sempre gênero e que, portanto, não existe uma essência interior e anterior aos gêneros. Quando se problematiza a relação dicotômica e determinista entre corpo e gênero, outros níveis constitutivos da identidade se liberam para compor arranjos múltiplos fora do referente binário (masculino e feminino) dos corpos.

E mais adiante ${ }^{27}$ :

[...] O/a "transexual oficial", por sua vez: a) odeia seu corpo, b) é assexuado/a e c) deseja realizar cirurgias para que possa exercer a sexualidade normal, a heterossexualidade, com o órgão apropriado. Sugiro, ao contrário, que eles/as não solicitam as cirurgias motivados/as pela sexualidade, tampouco são assexuados/as: querem mudanças em seus corpos para ter inteligibilidade social. Se a sociedade divide-se em corpos-homens e corpos mulheres, aqueles que não apresentam essa correspondência fundante tendem a estar fora da categoria humano. [...] As histórias de mulheres transexuais lésbicas e de homens transexuais gays indicam a necessidade de interpretar a identidade de gênero, a sexualidade, a subjetividade e o corpo como modalidades relativamente independentes no processo de constru-

\footnotetext{
${ }_{25}$ Sobre o tema da correlação do ser humano e sua sexualidade com o Direito, importante lembrar os ensinamentos de autores como Michel Foucault, o qual estudou com detalhes, na perspectiva da Filosofia, o tema da sexualidade em sua obra A História da Sexualidade. Para saber mais, vide: FOUCAULT, Michel. História da Sexualidade I: A vontade de saber. 18. ed. Rio de Janeiro: Graal, 1988.

${ }^{26}$ BENTO, Berenice. A reinvenção do corpo: sexualidade e gênero na experiência transexual. Rio de Janeiro: Garamond, 2006, p. 21.

${ }^{27}$ Idem, p. 25.
} 
ção das identidades.

Ainda assim, não obstante o caráter polêmico da questão e o uso da Medicina, é de se reiterar o posicionamento da jurista Jussara Meirelles, a qual lembra que o Direito não pode ficar aquém dessas discussões e deve buscar norteadores para uma melhor decisão. Cite-se ${ }^{28}$ :

$[\ldots]$

Todas as questões aqui lembradas, e muitas outras que a elas se relacionam direta ou indiretamente, necessitam de um traço jurídico nítido, porquanto dizem respeito às inquietudes sociais ante o crescente poder científico sobre a vida, a identidade e o destino das pessoas. Tais preocupações assumem caráter muito grave e sério para serem solucionadas tão somente em termos de consciência de cada um. $[\ldots]$

Ideal seria que, nas relações biotecnológicas, a vontade do profissional se convertesse na mesma vontade daquele que busca salvar-se ou curar-se. Hipoteticamente, haveria uma vontade única sem nem mesmo a necessidade de expressá-la. [...]

Fatos freqüentes e desastrosos mostram que a realidade se afasta desse idealismo. Existem situações, como aquela da hemodiálise em Seattle, nas quais é possível vislumbrar um verdadeiro conflito de vontade e de valores. Por essa razão, um problema de caráter clínico e ético adquire também um caráter jurídico. Emerge, daí, a finalidade do denominado Biodireito, qual seja a de fixar normas coercitivas que delimitem a atuação biotecnológica, no sentido de ver respeitada a dignidade, a identidade e a vida do ser humano. Todos esses elementos essenciais aos seres humanos vêm claramente assegurados na Constituição da República do Brasil.

Nesse mesmo vértice foi o entendimento do Ministro Dias Toffoli quando na análise da repercussão geral do RE 670422, segundo o qual a questão da (des) necessidade da realização de cirurgia de redesignação sexual, "extrapolam os interesses subjetivos das partes, pois, além de alcançarem todo o universo das pessoas que buscam adequar sua identidade de sexo à sua identidade de gênero, também repercutem no seio de toda a sociedade" 29 .

De toda forma, retomando as considerações iniciais, tem-se que as decisões ainda não são uniformes, dependendo essencialmente da visão pessoal do juiz e do

\footnotetext{
$\overline{28}$ MEIRELLES, Jussara. A questão do Biodireito sob a ótica da construção dos novos direitos no Brasil. In: MATOS, Ana Carla Harmatiuk (Org.). A construção dos novos direitos. Porto Alegre: Núria Fabris, 2008, v. 1, p. 217-218.

29 BRASIL, Supremo Tribunal Federal. Alteração do registro civil sem mudança de sexo será analisada pelo STF. Notícias do STF. Disponível em: < http://www.stf.jus.br/portal/cms/verNoticiaDetalhe.asp?idConteudo $=275563>$. Acesso em: 06 fev. 2015 .
} 
membro do Ministério Público ${ }^{30}$. Caberá ao STF, pois, quando no julgamento da ADI 4275 a árdua tarefa de esclarecer a necessidade ou não do procedimento cirúrgico aludido.

\section{CONSIDERAÇÕES FINAIS}

O tema da necessidade da realização da cirurgia de redesignação sexual é ainda polêmico, ao que propício para fins de estudo no ambiente acadêmico, sendo que impõe um olhar que se volta aos ditames constitucionais garantidores da dignidade e da identidade humana.

Conforme visto, para clarificar as ações iniciais que pleiteiam a alteração do nome/sexo constantes em registro civil há de se compreender, a priori, noções como a de identidade. Esta, ao seu turno, adquire variadas formas, abarcando a noção cultural, do nome e, inclusive, do sexo.

Os pedidos, ao menos enquanto aguarda-se a decisão do STF da ADI 4275, ficam à mercê de entendimentos variados: há aqueles que entendem pela necessidade da realização da cirurgia de redesignação sexual, enquanto há defensores da desnecessidade de realização da cirurgia de redesignação. Os fundamentos para tais argumentos também são os mais diversos, ora centrando-se em razões médicas, ora propugnando por fundamentos jurídicos, a exemplo dos princípios da veracidade dos documentos públicos e princípios da dignidade da pessoa humana.

\section{REFERÊNCIAS}

BARROSO, Luís Roberto. O controle de constitucionalidade no direito brasileiro: exposição sistemática da doutrina e análise crítica da jurisprudência. 6. ed., rev., atual. São Paulo: Saraiva, 2012.

BENTO, Berenice. A reinvenção do corpo: sexualidade e gênero na experiência transexual. Rio de Janeiro: Garamond, 2006.

BERTOLI, Clínica. Consentimento Informado Mastoplastia. Disponível em:

\footnotetext{
${ }_{30}$ BODIN DE MORAES, Maria Celina. A Tutela da Identidade Pessoal no Código de 2002, mimeo, p. 20.
} 
$<$ http://www.clinicabertoli.com.br/download/Consentimentos_Mastoplastia.pdf $>$. Acesso em: 10 fev. 2015.

BODIN DE MORAES, Maria Celina. A Tutela da Identidade Pessoal no Código de 2002. In: FÓRUM PERMANENTE SOBRE O DIREITO DE FAMÍLIA DA ESCOLA DA MAGISTRATURA DO RIO DE JANEIRO - EMERJ, 2000. Anais....

BRASIL. Constituição. Constituição da República Federativa do Brasil. Brasília, DF: Senado, 1988.

BRASIL. Estado de São Paulo. Indicação CEE no 126/2014 CP, aprovado em 30/4/2014. Disponível em: <www.centropaulasouza.sp.gov.br/cetec/geral/.../ cee/125_2014.docx >. Acesso em: 16 fev. 2015.

BRASIL. Lei no 6.015, de 31 de dezembro de 1973. Disponível em: < http://www. planalto.gov.br/ccivil_03/leis/6015compilada.htm > . Acesso em: 06 fev. 2015.

BRASIL. Supremo Tribunal Federal. ADI no 4275. Disponível em: < http://www.stf. jus.br/portal/processo/verProcessoAndamento.asp?incidente $=2691371>$. Acesso em: 06 fev. 2015.

BRASIL. Supremo Tribunal Federal. Alteração do registro civil sem mudança de sexo será analisada pelo STF. Notícias do STF. Disponível em: <http://www.stf. jus.br/portal/cms/verNoticiaDetalhe.asp?idConteudo=275563> . Acesso em: $06 \mathrm{fev}$. 2015.

BRASIL. Supremo Tribunal Federal, Glossário Jurídico. Disponível em: <http:// www.stf.jus.br/portal/glossario/> . Acesso em: 20 jul. 2014.

BRASIL. Supremo Tribunal Federal. Informativo STF. STA 223-AgR, Rel. p/ o C. Min. Celso de Mello, julgamento em 14-4-08, Plenário, Informativo $n^{0} 502$. Disponível em: <http://www.stf.jus.br/arquivo/informativo/documento/informativo502. htm > . Acesso em: 10 fev. 2015.

BRASIL. Superior Tribunal de Justiça. REsp 737993/MG. Rel. Min. João Otávio de Noronha, 4a Turma. DJ: 10/11/2009. Disponível em: < https://ww2.stj.jus.br/processo/revista/documento/mediado/?componente $=$ ATC $\&$ sequencial $=6511771 \&$ num 
registro $=200500486064 \&$ data $=20091218 \&$ tipo $=91 \&$ formato $=$ PDF $>. \quad$ Acesso em: 02 fev. 2015.

BRASIL. Tribunal de Justiça do Estado de Minas Gerais. Apelação Cível 1.0024.05.778220-3/001, Rel. Des.(a) Edivaldo George dos Santos, $7^{\mathrm{a}}$ CÂMARA CÍVEL, julgamento em 06/03/2009.

BRASIL. Tribunal de Justiça do Estado do Rio de Janeiro. Apelação no 2007.001.14071. Des. Gilberto Dutra Moreira, 10a CÂMARA CÍVEL. DJ: 05/09/2007.

BRASIL. Tribunal de Justiça do Estado de Sergipe, Apelação Cível no 4148/2012, $1^{\text {a }}$ Vara Cível de Estância, Juíza Convocada, Julgado em 04/12/2012.

CONSELHO FEDERAL DE MEDICINA. RESOLUÇÃO CFM no 1.955 de 12 de agosto de 2010. Dispõe sobre a cirurgia de transgenitalismo e revoga a Resolução CFM $\mathrm{n}^{\mathrm{o}}$ 1.652/02. Disponível em: <http://www.portalmedico.org.br/resolucoes/ CFM/2010/1955_2010.htm >. Acesso em: 10 fev. 2015.

CORDEIRO, Desiree Monteiro. Transtorno de Identidade de Gênero e mudança de prenome: laudo psicológico e justiça. Dissertação (Mestrado em Psiquiatria) Universidade de São Paulo. Disponível em: < http://www.teses.usp.br/teses/disponiveis/5/5142/tde-07122012-143732/pt-br.php > . Acesso em: 16 fev. 2015.

DA MATTA, Roberto. O que faz o brasil, Brasil? Rio de Janeiro: Rocco, 1986.

DE CUPIS, Adriano. O Direito à Identidade Pessoal. In: OS DIREITOS da personalidade. Tradução Antonio Celso Furtado Rezende. Campinas: Romana, 2004.

FOUCAULT, Michel. História da Sexualidade I: a vontade de saber. 13. ed. Tradução Maria Thereza da Costa Albuquerque e J.A. Guilhon Albuquerque. Rio de Janeiro: Graal, 1999. Disponível em: < https://repositorio.ufsc.br/bitstream/handle/123456789/1226/foucault_historiadasexualidade.pdf > . Acesso em: 30 mar. 2015.

FRIGNET, Henry. O transexualismo. Tradução Procópio Abreu. Rio de Janeiro: Companhia de Freud, 2002, p. 93.

MEIRELLES, Hely Lopes, Direito Administrativo Brasileiro. São Paulo, Malheiros, 2000 . 
MEIRELLES, Jussara. A questão do Biodireito sob a ótica da construção dos novos direitos no Brasil. In: MATOS, Ana Carla Harmatiuk. (Org.). A construção dos novos direitos. Porto Alegre: Núria Fabris, 2008, v. 1.

ORGANIZAÇÃO MUNDIAL DA SAÚDE. CID-10 Classificação Estatística Internacional de Doenças e Problemas Relacionados à Saúde. São Paulo: Universidade de São Paulo, 2013.

Recebido em: 18 de fevereiro de 2015 Aceito em: 12 de agosto de 2015 